Jurnal Sain Veteriner, Vol. 36. No. 1. Juni 2018, Hal. 32-39

DOI : $10.22146 /$ jsv.38444

ISSN 0126-0421 (Print), ISSN 2407-3733 (Online)

Tersedia online di https://jurnal.ugm.ac.id/jsv

\title{
Perbandingan Kinerja Berahi dan Level Estradiol Kambing Kacang dan Kambing Nubian yang Diinduksi dengan PGF2 $\alpha$
}

\section{Comparison of Estrous Performance and Estradiol Level between Kacang and Nubian Goats Induced with PGF2 $\alpha$}

\author{
Mulyadi Adam ${ }^{1}$, Raja Nurul Huda², Widya Zahara², Tongku Nizwan Siregar*, Hamdan ${ }^{3}$, \\ Sri Wahyuni ${ }^{4}$ Cut Nila Thasmi ${ }^{3}$, Rosmaidar ${ }^{5}$ \\ ${ }^{1}$ Laboratorium Fisiologi Fakultas Kedokteran Hewan Universitas Syiah Kuala, Banda Aceh \\ ${ }^{2}$ Program Studi Pendidikan Kedokteran Hewan Fakultas Kedokteran Hewan Universitas Syiah Kuala, Banda Aceh \\ ${ }^{3}$ Laboratorium Reproduksi Fakultas Kedokteran Hewan Universitas Syiah Kuala, Banda Aceh \\ ${ }^{4}$ Laboratorium Anatomi Fakultas Kedokteran Hewan Universitas Syiah Kuala, Banda Aceh \\ ${ }^{5}$ Laboratorium Farmakologi Fakultas Kedokteran Hewan Universitas Syiah Kuala, Banda Aceh \\ *Email: siregar@unsyiah.ac.id \\ Naskah diterima : 30 Mei 2017, direvisi : 6 Maret 2018, disetujui : 30 Mei 2018
}

\begin{abstract}
The experiment was conducted to compare estrous performance and estradiol level between Kacang and Nubian goats with PGF2 $\alpha$ - incluced estrous. Eight female goats were divided into two groups, groups 1 (K1) consisted five Nubian goats and group 2 (K2) included three kacang goats with criterias as follows: age 1.5-3.0 years old, not pregnant, at least two months postpartum, and healthy clinically. All goats were estrous synchronized by double injection 7,5 mg PGF2 $\alpha$ intramuscularly with 10 days interval. Goats that appeared estrus symptoms were mated naturally to a male goat. Determination of estrous intensity was performed using scoring method. Blood samples were taken at the first time the goats were mated (day 0). The measurement of estradiol concentration was done by enzyme linked immunosorbent assay (ELISA) method. Data of intensity, onset, duration, and estradiol level were analyzed using $t$ test. The results showed that the rate of intensity, onset, duration, and estradiol level of estrous at KI vs KII were $2.08 \pm 0.52$ vs $1.85 \pm 0.67,56.00 \pm 34.11$ vs $40.80 \pm 18.20$ hours, and $24.00 \pm 26.15$ vs $33.80 \pm 9.10$ hours, and $103.51 \pm 42.49$ vs $67.95 \pm 38.44 \mathrm{pg} / \mathrm{ml}(\mathrm{P}>0,05)$. It can be concluded there was no difference of estrous performance and estradiol level between Kacang and Nubian which estrous induction with PGF2 $\alpha$. The relationship between the intensity of estrus estradiol level in the Nubian goats was 0.995 while the Kacang goats was 0.890.
\end{abstract}

Key words: Kacang goat, Nubian goat, estrous performance, estradiol, PGF2

\begin{abstract}
Abstrak
Penelitian ini bertujuan mengetahui perbandingan kinerja berahi dan level estradiol kambing kacang dan kambing Nubian yang diinduksi dengan prostaglandin F2 alfa (PGF2 $\alpha$ ). Dalam penelitian ini digunakan delapan ekor kambing betina yang dibagi atas dua kelompok yakni kelompok I (KI) dan kelompok II (KII). Kriteria kambing yang digunakan adalah kondisi tubuh sehat secara klinis, sudah pernah beranak, dan berumur 1,5-3,0 tahun. Kelompok I (KI) terdiri atas tiga ekor kambing Kacang dan kelompok II (KII) terdiri atas lima ekor kambing Nubian. Seluruh kambing disinkronisasi berahi dengan PGF2 $\alpha$ sebanyak 7,5 mg secara intramuskulus dengan pola penyuntikan ganda dengan interval sepuluh hari. Deteksi estrus dilakukan tiga kali sehari yakni pada jam 06.00, 12.00, dan 18.00 WIB secara visual dan dibantu dengan pejantan pengusik. Penilaian intensitas berahi dilakukan dengan metode skoring. Sampel darah diambil pada hari ke-0 lalu dilakukan pengukuran konsentrasi estradiol. Data level intensitas, onset, dan durasi berahi serta level estradiol dianalisis menggunakan menggunakan uji t sedangkan hubungan intensitas berahi dengan konsentrasi estradiol dianalisis menggunakan uji korelasi dan regresi sederhana. Intensitas berahi; onset berahi; durasi berahi; dan level estradiol pada KI vs KII masing-masing adalah 2,08 $\pm 0,52$ vs 1,85 $\pm 0,67 ; 56,00 \pm 34,11$ vs $40,80 \pm 18,20$ jam; dan $24,00 \pm 26,15$ vs $33,80 \pm 9,10$ jam; $103,51 \pm 42,49$ vs $67,95 \pm 38,44 \mathrm{pg} / \mathrm{ml}(\mathrm{P}>0,05)$. Disimpulkan bahwa tidak terdapat perbedaan kinerja berahi dan level estradiol antara kambing kacang dan kambing Nubian yang mengalami induksi berahi dengan PGF2 $\alpha$. Hubungan antara intensitas berahi dengan konsentrasi estradiol pada kambing Nubian sebesar 0,995 dan pada kambing Kacang sebesar 0,89.
\end{abstract}

Kata kunci: estradiol, kambing Kacang, kambing Nubian, kinerja berahi, PGF2 


\section{Pendahuluan}

Faktor penting untuk meningkatkan produksi ternak adalah melalui produksi anak, yang tergantung pada kemampuan reproduksi induk dan cara pengaturannya. Untuk mempercepat produksi anak dan akhirnya menghasilkan susu dalam jumlah banyak maka diperlukan teknologi reproduksi yaitu dengan menyerentakkan berahi dan mengawinkan secara alami ataupun secara inseminasi buatan agar dapat diperoleh anak secara bersamaan (Adiati dan Praharani, 2013).

Sinkronisasi atau penyerentakan berahi pada ternak merupakan salah satu cara untuk dapat mempermudah pemeliharaan ternak dan dapat menghemat waktu dan tenaga kerja (Sianturi dkk., 1997). Sinkronisasi berahi merupakan salah satu upaya untuk menimbulkan berahi pada sekelompok ternak secara bersamaan. Hastono (2003) melaporkan bahwa usaha sinkronisasi berahi harus disertai juga dengan pengamatan terhadap tanda-tanda estrus secara visual dengan cermat agar tercapainya angka konsepsi yang tinggi.

Salah satu protokol untuk sinkronisasi berahi adalah melalui penggunaan prostaglandin F2 alfa (PGF2a). Sinkronisasi berahi menggunakan PGF2a bertujuan meregresi korpus luteum pada fase luteal, yang akan menurunkan kadar progesteron dalam plasma darah (Thatcher dkk., 2001). Penurunan kadar progesteron ini akan merangsang hipofisis anterior menghasilkan dan melepaskan follicle stimulating hormone (FSH) dan luteinizing hormone (LH). Kedua hormon ini bertanggungjawab dalam proses folikulogenesis dan ovulasi, sehingga terjadi pertumbuhan dan pematangan folikel. Folikel-folikel tersebut akhirnya menghasilkan hormon estrogen yang mampu memanifestasikan gejala berahi (Hafez dan Hafez, 2000).

Untuk mengukur efektivitas sinkronisasi berahi maka diperlukan data mengenai kinerja berahi setelah perlakuan sinkronisasi berahi. Beberapa laporan menunjukkan bahwa kinerja berahi dipengaruhi oleh breed. Sapi Brahman memiliki durasi dan intensitas estrus yang lebih rendah dibandingkan dengan sapi Bos taurus (Landaeta-Hernandez dkk., 2002). Praharani (2011) melaporkan bahwa tingkat estrus pada sapi Brahman lebih rendah dibandingkan dengan sapi Brahman persilangan, karena adanya gen Bos taurus dalam darah sapi Brahman persilangan.

Selain kinerja berahi, efektivitas sinkronisasi berahi dapat diketahui melalui metode pengukuran kadar estrogen. Lymo dkk. (1999) menyatakan bahwa intensitas estrus berkaitan dengan kadar hormon estradiol dalam darah sapi dengan korelasi sebesar 0,7. Hormon estrogen merupakan hormon yang bertanggung jawab terhadap manifestasi munculnya gejala berahi.

Popalayah dkk. (2013) melaporkan, profil estrogen kambing Bligon pada saat estrus adalah $108,13 \pm 59,02$ pg/ml. Selanjutnya, Akusu dkk. (2006) melaporkan konsentrasi estradiol pada kambing West African Dwarfs (WAD) pada saat berahi 152,62 $\pm 31,6$ $\mathrm{pg} / \mathrm{ml}$. Perbedaan breed diduga memengaruhi konsentrasi estradiol pada saat berahi. Siregar dkk. (2016) melaporkan konsentrasi estradiol sapi Aceh pada saat estrus adalah $223,13 \pm 9,50 \mathrm{pg} / \mathrm{ml}$. Konsentrasi estradiol sapi Aceh pada saat berahi relatif lebih tinggi dibandingkan konsentrasi estradiol sapi perah yakni 25 pg/ml (Henricks dkk., 2013), antara $26,75 \pm 8,63$ sampai dengan $52,91 \pm 12,99 \mathrm{pg} / \mathrm{ml}$ pada sampel segar dan beku (Domenech dkk., 2011), 20,24 pg/ml pada sapi Punganur (Naik dkk., 2013). Konsentrasi estradiol sapi Bali pada saat berahi adalah 107,77 $\pm 55,94$ pg/ml (Arin dkk., 2014). Sampai saat ini, belum ada laporan mengenai perbedaan kinerja berahi dan level estradiol antara kambing Kacang dan kambing Nubian. 


\section{Materi dan Metode}

Penelitian ini dilakukan di Unit Pelaksana

Teknis (UPT) Hewan Coba Fakultas Kedokteran Hewan Universitas Syiah Kuala Banda Aceh dan UD. Atjeh Livestock pada bulan Desember 2016 sampai Januari 2017. Dalam penelitian ini digunakan lima ekor kambing Nubian dan tiga ekor kambing Kacang dengan kriteria sehat secara klinis, sudah pernah beranak, dan umur 1,5-3,0 tahun. Selain itu, untuk membantu observasi berahi, digunakan satu ekor hewan jantan.

\section{Prosedur Penelitian}

Kambing dibagi atas dua kelompok perlakuan yakni KI untuk kelompok kambing Kacang dan KII untuk kelompok kambing Nubian. Seluruh kambing betina diinjeksi dengan 7,5 mg PGF2 $\alpha$ (Lutalyse $^{\mathrm{TM}}$, Pfizer, Belgia) secara intramuskulus, dua kali injeksi dengan interval sepuluh hari. Pengamatan berahi dilakukan tiga kali sehari yakni (pukul 06.00, 12.00, dan 18.00 WIB). Lama pengamatan terhadap betina dilakukan selama \pm 1 jam secara visual dan dibantu dengan pejantan pengusik yang dimulai sejak penyuntikan PGF2 $\alpha$ terakhir selama empat hari.

\section{Skoring Intensitas Berahi}

Pengamatan visualisasi respons berahi terdiri atas tingkah laku diam dinaiki, kemerahan mukosa vulva, kebengkakan vulva, dan kekentalan lendir yang dikuantifikasi dalam bentuk skor. Tingkah laku betina terhadap jantan diberi skor 3 jika diam dinaiki, skor 2 jika ragu-ragu ketika dinaiki, dan skor 1 jika tidak menunjukkan reaksi. Warna mukosa merah diberi skor 3, skor 2 untuk merah muda, dan skor 1 untuk merah muda kepucatan. Kebengkakan vulva diberi skor 3 jika vulva mengalami pembengkakan dengan ukuran dua kali dari kondisi normal, skor 2 jika vulva hanya mengalami sedikit pembengkakan, dan skor 1 jika vulva tidak mengalami pembengkakan. Kekentalan lendir diberi skor 3 jika sekreta bersifat viscous, bening menggantung atau membasahi sekitar vulva, skor 2 jika jumlahnya sedikit, dan skor 1 jika tidak ada sekreta (Santoso dkk., 2014). Skor berahi merupakan penjumlahan dari masing-masing kriteria berahi dan dibagi empat. Skoring tertinggi pada periode pengamatan dihitung sebagai skor berahi masingmasing kambing.

\section{Pengambilan Sampel Darah}

Pengambilan sampel darah dilakukan pada saat estrus yang ditentukan sebagai hari ke-0, yakni pada saat kambing pertama kali mau dinaiki. Darah untuk pengukuran konsentrasi hormonal diambil dari vena jugularis kambing menggunakan disposible syringe $5 \mathrm{ml}$. Darah dimasukkan ke dalam tabung reaksi kemudian dibawa ke Laboratorium Riset untuk diambil serumnya. Sentrifugasi dilakukan dengan kecepatan $2.500 \mathrm{rpm}$ selama 15 menit. Serum kemudian dimasukkan dalam tabung mikro dan dimasukkan dalam freezer dengan suhu $-20^{\circ} \mathrm{C}$ sampai saat digunakan untuk analisis hormonal.

\section{Pengukuran Konsentrasi Estradiol}

Pengukuran konsentrasi hormone estrogen dilakukan dengan metode ELISA menggunakan kit ELISA estradiol (EIA DRG Instruments GmbH, Germany). Pengukuran estradiol ini memiliki sensitivitas sebesar $9,72 \mathrm{pg} / \mathrm{ml}$ serta variasi intra assay dan variasi inter assay masing-masing sebesar 4,76\% dan $6,53 \%$.

\section{Onset berahi}

Onset berahi adalah waktu yang diperlukan mulai dari penyuntikan PGF2 $\alpha$ terakhir sampai munculnya gejala berahi dan dinyatakan dalam jam. Gejala berahi dinyatakan muncul jika nilai skor intensitas berahi $>1$.

\section{Durasi berahi}

Durasi berahi adalah waktu mulai dari munculnya gejala berahi setelah perlakuan sampai gejala berahi tersebut hilang dan dinyatakan dalam jam. Gejala berahi dinyatakan hilang jika nilai skor intensitas berahi sama dengan 1 . 


\section{Analisis Data}

Data kinerja berahi yang meliputi intensitas, onset, dan durasi berahi serta level estradiol dianalisis menggunakan uji t sedangkan hubungan intensitas berahi dengan konsentrasi estradiol dianalisis menggunakan uji korelasi dan regresi sederhana.

\section{Hasil dan Pembahasan}

Seluruh kambing baik yang diinduksi dengan PGF $2 \alpha$ menunjukkan respons estrus. Intensitas, onset, dan durasi berahi pada pada KI dan KII menunjukkan perbedaan yang tidak signifikan $(\mathrm{P}>0,05)$ seperti yang disajikan pada Tabel 1.

Tabel 1. Perbandingan kinerja berahi kambing Kacang dan kambing Nubian yang mengalami induksi berahi dengan PGF2 $\alpha$

\begin{tabular}{lcccc}
\hline Jenis ka mbing & $\begin{array}{c}\text { Jumlah } \\
\text { Samp el }\end{array}$ & \multicolumn{3}{c}{ Rata-rata \pm SD } \\
\cline { 3 - 5 } & 3 & $2,08 \pm 0,52^{\text {a }}$ & $56,00 \pm 34,11$ & $24,00 \pm 26,15^{\text {a }}$ \\
berahi & & & \\
\hline $\begin{array}{l}\text { Kambing Kacang } \\
(\text { KI) }\end{array}$ & 5 & $1,85 \pm 0,67^{\text {a }}$ & $40,80 \pm 18,20^{\text {a }}$ & $33,80 \pm 9,10^{\text {a }}$ \\
$\begin{array}{l}\text { Kambing Nubian } \\
(\text { KII })\end{array}$ & 5 & $\begin{array}{c}\text { Onset berahi } \\
\text { (jam })\end{array}$ & \\
\hline
\end{tabular}

${ }^{\mathrm{a}}$ Superskrip yang sama pada kolom yang sama memperlihatkan perbedaan yang tidak nyata $(\mathrm{P}>0,05)$.

Tanda betina yang sedang estrus menampakkan beberapa macam gejala, seperti vulva bengkak dan merah, berlendir, urinasi berlebihan, dan diam ketika dinaiki pejantan. Tanda-tanda berahi hasil penelitian ini sesuai dengan yang dikemukakan oleh Siregar dkk. (2004). Respons kambing terhadap metode pemberian PGF2 $\alpha$ dapat menyebabkan regresinya korpus luteum fungsional dan memungkinkan dimulainya siklus baru, yang menyebabkan timbulnya berahi (Siregar dkk., 2001).

Kambing Kacang maupun kambing Nubian menunjukkan respons yang baik terhadap implementasi sinkronisasi berahi dengan PGF2 $\alpha$. Siregar dkk. (2001) melaporkan injeksi tunggal prostaglandin terbukti menghasilkan $80 \%$ kambing berahi, sedangkan injeksi kedua yang dilakukan sepuluh hari kemudian akan menghasilkan 100\% berahi. Injeksi awal PGF2 $\alpha$ akan menyebabkan kambing mencapai fase pertengahan luteal dari siklus berahi. Injeksi kedua akan efektif mempersingkat masa hidup korpus luteum dengan cara melisisnya (Hunter, 1995). Romano (1998) dan Ahmed dkk.
(1998) melaporkan kambing Nubian yang diinjeksi PGF2 $\alpha$ sebanyak dua kali dengan selang waktu 12-13 hari memberikan respons estrus sebanyak 100\%. Hasil dari penelitian Syafruddin dkk. (2016), kambing Kacang juga menunjukkan respons yang baik terhadap implementasi sinkronisasi berahi dengan PGF2 $\alpha$ secara ganda dengan interval sepuluh hari yakni sebanyak $100 \%$.

Penyuntikan PGF $2 \alpha$ pada betina menyebabkan lisisnya korpus luteum sehingga kadar hormon progesteron di dalam darah menurun. Kadar progesteron yang turun menimbulkan rebound effect, yakni pelepasan hormon gonadotropin FSH dan LH dari kelenjar hipofisis bagian anterior yang disintesis dan ditimbun selama kadar progesteron tinggi. Hormon FSH dan LH akan merangsang pematangan folikel sehingga menghasilkan hormon estrogen yang menyebabkan betina menjadi estrus (Rizal dkk., 2014).

Intensitas berahi yang diperoleh pada kambing kacang dan kambing Nubian masing-masing $2,08 \pm 0,52$ dan $1,85 \pm 0,67$. Pada kambing kacang 
intensitas berahi relatif lebih tinggi dari pada kambing Nubian meskipun secara statistik tidak signifikan $(\mathrm{P}>0,05)$. Perbedaan intensitas estrus antar individu terutama dipengaruhi oleh kadar estrogen di dalam darah. Semakin tinggi estrogen yang dihasilkan oleh individu hewan maka estrus akan semakin jelas terlihat, terutama munculnya kemerahan dan kebengkakan pada vulva (Popalayah dkk., 2013). Hal ini mendukung pendapat Lyimo dkk. (1999), bahwa intensitas estrus berkaitan dengan kadar hormon estradiol dalam darah sapi dengan korelasi sebesar 0,7 .

Perbedaan intensitas berahi meskipun tidak signifikan $(\mathrm{P}>0,05)$ pada penelitian ini kemungkinan disebabkan oleh faktor breed yang berbeda. Hafizuddin dkk. (2012) melaporkan intensitas berahi dengan jelas antara sapi yang disinkronisasi berahi dan berahi alami masing-masing adalah 60 dan 70\%, sedangkan pada sapi Bali Timor, yang mendapatkan intensitas berahi jelas antara sapi yang disinkronisasi berahi dan berahi alami dengan persentase masingmasing sama yakni 71,42\% (Kune dan Solihati 2007). Jiménez dkk. (2011), melaporkan bahwa sapi dari Bos indicus cenderung menunjukkan intensitas berahi yang rendah dan durasi berahi yang pendek dibandingkan dengan breed sapi lainnya.

Onset berahi antara kedua kelompok menunjukkan perbedaan yang tidak nyata $(\mathrm{P}>0,05)$, namun onset berahi cenderung lebih cepat pada kambing Nubian dibandingkan kambing Kacang yakni

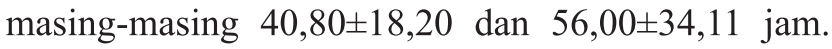
Menurut Sonjaya (1993) keragaman onset estrus pada setiap individu sangat dipengaruhi oleh aktivitas ovarium, terutama adanya korpus luteum yang aktif dan normal tidaknya siklus reproduksi.

Onset estrus lebih cepat terjadi pada ternak yang telah melahirkan lebih dari satu kali dibandingkan dengan ternak yang melahirkan satu kali atau ternak yang sama sekali belum pernah melahirkan (Ismail, 2009). Menurut Nuryadi (1982) terdapat korelasi sangat nyata antara umur dan angka ovulasi, setiap umur bertambah satu tahun, angka ovulasinya bertambah 0,14 . Ternak kambing yang lebih dari satu kali melahirkan dan pada setiap kelahiran memiliki anak kembar adalah hasil dari ovulasi ganda atau lebih, menyebabkan kandungan estrogen yang disekresikan ke dalam darah akan lebih banyak pula, sehingga berakibat lebih cepat terjadinya estrus jika dibandingkan dengan ternak yang hanya menghasilkan ovulasi tunggal. Jumlah ovulasi dipengaruhi oleh faktor genetik dan lingkungan atau interaksi keduanya (Ahmad dkk., 1996). Hasil penelitian Sodik dan Sumaryadi (2002) menunjukkan bahwa rata-rata jumlah anak per kelahiran untuk kambing Kacang dan PE masing-masing 2,06 dan 1,56 anak per kelahiran, sedangkan Subandriyo (1993) melaporkan rata-rata jumlah anak sekelahiran kambing Kacang dan PE sebesar 1,65 dan 1,50 anak per kelahiran. Perbedaan jumlah ovulasi yang dimanifestasikan dengan jumlah anak ini kemungkinan berhubungan dengan onset berahinya. Sampai sejauh ini, belum terdapat laporan produktivitas kambing Nubian di Indonesia.

Durasi berahi pada kambing Kacang cenderung lebih singkat dibandingkan dengan kambing Nubian yakni masing-masing 24,00 $\pm 26,15$

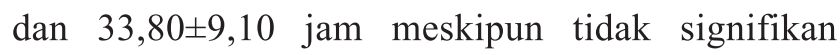
$(\mathrm{P}>0,05)$. Durasi berahi pada kambing bervariasi mulai 8-32 jam. Dari hasil penelitian rata-rata durasi berahi pada kambing Kacang dan kambing Nubian masih tergolong normal. Syafruddin dkk. (2011) melaporkan durasi kambing lokal Aceh yang diinduksi dengan PGF2 $\alpha$ adalah $26,67 \pm 4,62$ jam. Hasil penelitian lain menunjukkan bahwa durasi kambing Afrika yang disinkronisasi dengan PGF2 $\alpha$ yakni 32,40 $\pm 3,60$ jam (Mngongo, 1987), 43,75 $\pm 12,27$ jam (Purwanti, 1989),

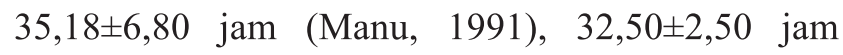

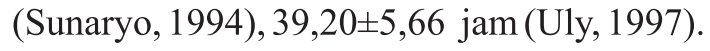

Walaupun secara statistik tidak berbeda, namun durasi berahi kambing Kacang lebih cepat 
dibandingkan dengan kambing Nubian. Perbedaan durasi berahi dapat disebabkan oleh faktor breed dan pola pemeliharaan yang berbeda. Suharyati (1999) melaporkan durasi estrus banyak dipengaruhi oleh beberapa faktor seperti bangsa, umur, dan musim. Dewi dkk. (2011) melaporkan durasi estrus pada

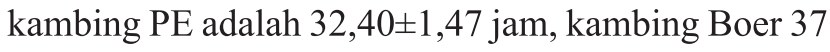
jam (Tambing dkk., 2001), dan domba Garut 30,95 \pm 4,32 jam (Setiadi dan Aepul., 2010).

Intensitas berahi yang tidak berbeda antar kelompok $(2,08 \pm 0,52$ vs $1,85 \pm 0,67)$ dapat dijelaskan dari perbedaan yang tidak signifikan pada konsentrasi estradiol. Hubungan intensitas berahi dengan konsentrasi estradiol pada kambing Nubian sebesar 0,995 dengan persamaan regresi $\mathrm{y}=40,416+-16,241 \mathrm{x}$ sedangkan hubungan intensitas berahi dengan konsentrasi estradiol kambing kacang sebesar 0,890 dengan persamaan regresi $y=75,632+-85,565 x ; y$ adalah skor intensitas berahi sedangkan $\mathrm{x}$ adalah konsentrasi estradiol. Hasil ini mendukung pendapat Lymo dkk. (1999), bahwa kejadian sifat estrus berkaitan dengan kadar hormon estradiol dalam darah sapi.

Dari hasil penelitian diperoleh rata-rata $( \pm \mathrm{SD})$ konsentrasi estradiol pada KI dan KII masing-masing adalah 103,51 $\pm 42,49$ dan $67,95 \pm 38,44 \mathrm{pg} / \mathrm{ml}$ $(\mathrm{P}>0,05)$. Hasil pengukuran konsentrasi estradiol pada penelitian ini lebih tinggi dari hasil penelitian Blaszyk dkk. (2004) pada kambing perah Angol Nubian yang memiliki konsentrasi estradiol 15,3 $\pm 5,04 \mathrm{pg} / \mathrm{ml}$. Selanjutnya, Popalayah dkk. (2013) melaporkan konsentrasi estradiol pada saat estrus pada kambing Bligon adalah 108,129 $\pm 59,02$ pg/ml. Meskipun secara statistik tidak berbeda, kambing Kacang pada penelitian ini cenderung memiliki konsentrasi estrogen yang lebih tinggi dibandingkan kambing Nubian. Variasi konsentrasi estrogen dapat disebabkan adanya perbedaan kemampuan untuk memproduksi estrogen di antara individu maupun breed. Hal ini sesuai dengan peryataan Sunendar (2008) bahwa konsentrasi hormon yang berbeda-beda pada hewan sangat tergantung pada jenis hewan, ras, umur dan waktu pengukurannya. Leyva-Ocariz dkk. (1995) melaporkan bahwa konsentrasi hormon estrogen meningkat pada saat terjadinya estrus sekitar $28 \pm 0,6$ pg/ml pada kambing lokal (kambing kacang), dan $24 \pm 0,8 \mathrm{pg} / \mathrm{ml}$ pada kambing persilangan (kambing Bligon).

\section{Kesimpulan}

Dari hasil penelitian disimpulkan bahwa tidak terdapat perbedaan kinerja berahi dan level estradiol saat berahi antara kambing Kacang dan kambing Nubian yang mengalami induksi berahi dengan PGF2 $\alpha$. Hubungan antara intensitas berahi dengan konsentrasi estradiol pada kambing Nubian adalah 0,995 sedangkan pada kambing Kacang sebesar 0,890.

\section{Daftar Pustaka}

Adiati, U. dan Praharani, L. (2013). Pengaruh jenis sinkronisasi waktu penyuntikan PMSG terhadap kinerja berahi pada ternak kambing Peranakan Etawah dan Sapera. Prosiding Seminar Nasional Teknologi Peternakan dan Veteriner, Medan: 326-330.

Ahmad, N., Beam, S.W., Butler, W.R., Deaver, D.R., Duby, R.T., Elder, D.R., Fortune, J.E., Griel, L.C., Jones Jr, L.S., Milvae, R.A., Pate, J.L., Reva, I., Schreiber Jr D.T., Townson, D.H., Tsang, P.C.W., and Inskeep E.K. (1996). Relationship of fertility to patterns of ovarian follicular development and associated hormonal profiles in dairy cow and heifers. J. Anim. Sci. 74: 1943-1952.

Ahmed, M.M.M., Makawi, S.E. and Jubara A.S. (1998). Synchronization of oestrus in Nubian goats. Small. Rum. Res. 30: 113-120.

Akusu, M.O., Nduka, E., and Egbunike, G.N.. (2006). Peripheral plasma levels of progesterone and oestradiol-17 during the reproductive cycle of West African D warf goat s. 520B/x5520bOp.htm. Diakses pada tanggal 17 Oktober 2016.

Arin, C.M., Putro, P.P., Astuti, P. dan Baliarti, E. 
(2014). Level of estradiol 17- $\beta$ serum and ovarian folliculare dynamics in short estrous cycle of bali cattle. J. Indonesian Trop. Anim. Agric. 39(1): 23-29.

Blaszczky, B., Udala, J. and Gaczarzewicz, D. (2004). Change in estradiol, progesterone, melatonin, prolactin and thyroxine concentration in blood plasma of goat following induced estrus in and outside the natural breeding season. Small Rum. Res. 51:209-219.

Dewi, R.R., Wahyuningsih, dan Widayati D.T. (2011). Respons estrus pada kambing peranakan ettawa dengan body condition score 2 dan 3 terhadap kombinasi implant controlled internal drug release jangka pendek dengan injeksi prostaglandin F2 alpha. J. Ked. Hewan. 5(1): 1116.

Domenech, A., Pich, S., Arís, A., Plasencia, C., Bach, A. and Serrano, A. (2011). Heat identification by $17 \beta$-estradiol and progesterone quantification in individual raw milk samples by enzyme immunoassay. Electronic J. Biotechnol. 14(4): $0.2225 /$ vol14-issue4-fulltext-6.

Hafez, B. and E.S.E. Hafez. 2000. Reproduction in Farm Animals. $7^{\text {th }}$ ed. Lea and Febiger Co., Philadelphia. USA:75-89.

Hafizuddin, Siregar, T.N. dan Akmal, M. (2012). Hormon dan perannya dalam dinamika folikuler pada hewan domestik. JESBIO. 1(1): 17-23.

Hastono. (2003). Usaha perbaikan kinerja reproduksi induk kambing dan domba. Prosiding Seminar Nasional Teknologi Peternakan dan Veteriner. Puslitbang Peternakan. Balai Penelitian Ternak, Bogor: 96-98.

Henricks, D.M., Dickey, J.F. and Niswender, G.D. (1970). Plasma estrogen and progesterone levels after mating, and during late pregnancy and postpartum in cows. Biol. Reprod. 2:346-351.

Hunter, R.H.F. (1995). Fisiologi Teknologi Reproduksi Hewan Betina Domestik. Edisi ke-2. Terjemahan D. K. Harya Putra. Penerbit ITB. Bandung: 38-43.

Ismail, M. (2009). Onset dan intensitas estrus kambing pada umur yang berbeda. J. Agroland. 16(2): 180-186.

Jiménez, L.M., Sánchez-Mendoza, M.E., ReyesRamírez, A., Antonio, L.C., Rodríguez-Silverio,
J. and Arrieta, J. (2011). Bioassay-guided isolation of an anti-ulcer compound, tagitinin C, from Tithonia diversifolia: Role of nitric oxide, prostaglandins and sulfhydryls. Molecules. 16(1): 665-674.

Kune, P. dan Solihati, N. (2007). Tampilan berahi dan tingkat kesuburan sapi bali timor yang diinseminasi. J. Ilmu Ternak. 7(1): 1-5.

Landaeta-Hernández, A.J., Yelich, J.V., Lemaster, J.W., Fields, M.J., Tran, T., Chase Jr. C.C., Rae, D.O. and Chenoweth, P.J. (2002). Environmental, genetic and social factors affecting the expression of estrus in beef cows. Theriogenology. 57(4): 1357-1370.

Lyimo, Z.C., Nielen, M., Ouweltjes, W., Kruip, T.A.M. and van Eerdenburg, F.J.C.M. (2000). Relationship among estradiol, cortisol and intensity of estrous behavior in dairy cattle. Theriogenology. 53: 1783-1795.

Manu, A.E. (1991). Pengaruh pemberian PGF2 alpha terhadap sinkronisasi birahi pada ternak kambing kacang. Skripsi. Fakultas Peternakan, Universitas Nusa Cendana, Kupang.

Mngongo, F.O.K. (1987). Doses of prostaglandin a n a log u "cloprostanol" intravulvasubmucosal (IVSM) injection effective for the induction oestrous in goats.Anim. Reprod. Sci. 14:139-146.

Nuryadi. 1982. Angka kematian pra lahir domba ekor gemuk sesuai dengan umur, jumlah dan posisi ovulasi dari induk. Tesis. Fakultas Pasca Sarjana Institut Pertanian Bogor, Bogor.

Popalayah, Ismayah, dan Ngadiono N. (2013). Efektivitas penggunaan controlled internal drug release (CIDR) terhadap respons estrus. Buletin Peternakan. 37: 148-156.

Praharani, L. (2011). Respon sinkronisasi estrus sapi Brahman dan persilangannya. Seminar Nasional Teknologi Peternakan Dan Veteriner. Balai Penelitian Ternak. Bogor: 23-26.

Purwanti, M. (1989). Superovulasi dan Panen Embrio pada Kambing Kacang. Tesis. Program Pascasarjana, Universitas Gajah Mada, Yogyakarta.

Rizal, M., Irawan, B., Biyatmoko, D., Wahi, A., Habibah dan Riyadhi, A. (2014). Keberhasilan kebuntingan kambing peranakan Ettawa yang 
diinseminasi dengan semen cair. Agrinimal. 4(1): 2-5.

Romano, J.E. (1998). Effect of two doses of cloprostenol in two schemes for estrous synchronization in Nubian goats. Small. Rum. Res. 28: 171-176.

Santoso, Amrozi, Purwantara, B. dan Herdis. (2014). Gambaran ultrasonografi ovarium kambing kacang yang disinkronisaasi dengan hormon prostaglandin F2 alfa (PGF2 $\alpha$ ) dosis tunggal. J. Ked. Hewan. 8(1): 38-42.

Setiadi, M.A. dan Aepul. (2010). Estrous characteristic in Garut sheep after estrous synchronization using prostaglandin and progesterone-CIDR. Proceeding SEAVSA Congress; Bogor, 20-22 Juli 2010:121-122.

Sianturi, R.S.G., Adiati, U., Hastono, Budiarsana, I.G.M. dan Sutama, I.K. (1997). Sinkronisasi birahi secara hormonal pada kambing peranakan Etawah. Seminar Nasional Teknologi Peternakan Dan Veteriner. Balai Penelitian Ternak. Bogor: 45-47.

Siregar, T.N., Areuby, N., Riady, G. dan Amiruddin. (2004). Efek pemberian PMSG terhadap respon ovarium dan kualitas embrio kambing lokal prepuber. Media Ked. Hewan. 20(3): 108-112.

Siregar, T.N., Melia, J., Rohaya, R., Thasmi, C.N., Masyitha, D., Wahyuni, S., Rosa, J., Nurhafni, N., Panjaitan, B., and Herrialfian, H. (2016). Determining proportion of exfoliative vaginal cell during various stages of estrus cycle using vaginal cytology techniques in aceh c a t t $1 \mathrm{e}$. Ve $t . M e d . \quad I n t$. http://dx.doi.org/10.1155/2016/3976125.

Siregar, T.N., Riady, G., Al Azhar, Budiman, H. dan Armansyah, T. (2001). Pengaruh pemberian prostaglandin F-2 alfa secara intravulvasubmukosal terhadap tampilan reproduksi kambing lokal. J. Med. Vet. 1(2): 6165 .

Sodiq, A. and Sumaryadi, M.Y. (2002). Reproductive performance of kacang and Peranakan Etawah Goat in Indonesia. J. Anim. Prod. 8: 52-59.

Sonjaya, Panturu, H.D. dan Rawasiah, Y. (1993). Respons ovarium kambing kacang terhadap perlakuan superovulasi dan suplementasi konsentrat. Bulletin Ilmu Peternakan dan Perikanan Unhas. II(5): 10-19.
Subandriyo. (1993). Potensi dan Produkstivitas Ternak Kambing di Indonesia. Lokakarya Potensi dan Pengembangan Ternak Kambing di Wilayah Indonesia Bagian Timur. Dinas Peternakan. Jawa Timur.

Suharyati, S. (1999). Pengaruh pemberian pregnant mare serum gonadotrophin dan human chorionic gonadotrophin terhadap kinerja reproduksi kambing peranakan Ettawah yang disinkronisasi estrus dengan progesteron. Tesis. Program Pascasarjana, Universitas Gadjah Mada, Yogyakarta.

Sunaryo B. 1994. Pengaruh penggunaan PGF2 alpha dan GnRH sintetik untuk optimalisasi hasil inseminasi buatan pada kambing PE. Skripsi. Fakultas Kedokteran Hewan, Universitas Gadjah Mada, Yogyakarta.

Sunendar. 2008. Profil implant progesteron dan estrogen pada kambing Peranakan Etawa (PE) yang disinkronisasi estrus dengan implant CIDR. Tesis. Pascasarjana Universitas Gadjah Mada, Yogyakarta.

Syafruddin, Melia, J., Armansyah, T., Siregar, T.N., Riady, G., Dasrul, Panjaitan, B. dan Hamdan. (2016). Perbandingan kinerja berahi kambing kacang dan kambing peranakan Etawah (PE) yang mengalami induksi berahi dengan PGF2 alfa. J. Med. Vet. 10(1): 55-58.

Syafruddin, Siregar, T.N., Herrialfian, Armansyah, T., Sayuti, A. dan Roslizawaty. (2011). Efektivitas pemberian ekstrak vesikula seminalis terhadap persentase berahi dan kebuntingan pada kambing lokal. J. Ked. Hewan. 4(2): 53-60.

Tambing NS, Gazali M, Purwantara B. 2001. Pemberdayaan teknologi inseminasi buatan pada ternak kambing. Wartazoa.Vol.11 No.1.

Thatcher, W.W., Moreira, W. and Risco, W.A. (2001). Strategies to optimize reproductive efficiency by regulation of ovarian function. Dom. Anim. Endocrinol. 23:243-254.

Uly, K. 1997. Respon birahi dan angka kebuntingan kambing PE dengan Pemberi-an PGF2 alpha $\mathrm{s}$ e c a r a i t r a m u k u la r d a n intravulvasub-mukosal. Tesis. Program Pascasarjana, Universitas Gadjah Mada, Yogyakarta. 